\title{
Dwelling in Resistance
}




\title{
Nature, Society, and Culture
}

\author{
Scott Frickel, Series Editor
}

A sophisticated and wide-ranging sociological literature analyzing naturesociety-culture interactions has blossomed in recent decades. This book series provides a platform for showcasing the best of that scholarship: carefully crafted empirical studies of socio-environmental change and the effects such change has on ecosystems, social institutions, historical processes, and cultural practices.

The series aims for topical and theoretical breadth. Anchored in sociological analyses of the environment, Nature, Society, and Culture is home to studies employing a range of disciplinary and interdisciplinary perspectives and investigating the pressing socio-environmental questions of our timefrom environmental inequality and risk, to the science and politics of climate change and serial disaster, to the environmental causes and consequences of urbanization and war making, and beyond.

Available titles in the Nature, Society, and Culture series:

Diane C. Bates, Superstorm Sandy: The Inevitable Destruction and Reconstruction of the Jersey Shore

Cody Ferguson, This Is Our Land: Grassroots Environmentalism in the Late Twentieth Century

Stefano B. Longo, Rebecca Clausen, and Brett Clark, The Tragedy of the Commodity: Oceans, Fisheries, and Aquaculture

Stephanie A. Malin, The Price of Nuclear Power: Uranium Communities and Environmental Justice

Chelsea Schelly, Dwelling in Resistance: Living with Alternative Technologies in America

Diane Sicotte, From Workshop to Waste Magnet: Environmental Inequality in the Philadelphia Region

Sainath Suryanarayanan and Daniel Lee Kleinman, Vanishing Bees: Science, Politics, and Honeybee Health 


\section{Dwelling in Resistance}

\section{Living with Alternative \\ Technologies in America}

CHELSEA SCHELLY



Rutgers University Press

New Brunswick, Camden, and Newark, New Jersey, and London 


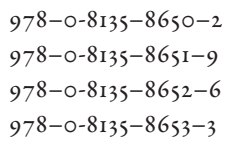

Cataloging-in-Publication data is available from the Library of Congress.

A British Cataloging-in-Publication record for this book is available from the British Library.

\section{Copyright (C) 2017 by Chelsea Schelly}

All rights reserved

No part of this book may be reproduced or utilized in any form or by any means, electronic or mechanical, or by any information storage and retrieval system, without written permission from the publisher. Please contact Rutgers University Press, I0 6 Somerset Street, New Brunswick, NJ 0890 . The only exception to this prohibition is "fair use" as defined by U.S. copyright law.

$\infty$ The paper used in this publication meets the requirements of the American National Standard for Information Sciences-Permanence of Paper for Printed Library Materials, ANSI Z39.48-1992.

www.rutgersuniversitypress.org

Manufactured in the United States of America 
For Avery, always 
